\title{
Physiological characteristics of corn intercropped with different arrangements of palisade grass plants
}

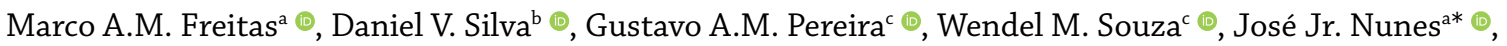 \\ Antonio A. Silva ${ }^{c}($ ) \\ a Instituto Federal Goiano, Urutaí, GO, Brazil. ' ${ }^{\circ}$ Universidade Federal Rural do Semi-Árido, Mossoró, RN, Brazil. c Universidade Federal de Viçosa, \\ Viçosa, MG, Brazil.
}

Abstract: Background: The study of corn and palisade grass physiology may assist in determining the best arrangement of the plants and more efficient management of this intercropped system.

Objective: To evaluate the effects of different palisade grass plant arrangements and their control on physiological characteristics and corn yield.

Methods: Two trials in randomized complete block design with four replications were conducted in field conditions. In the first, corn was sown with $0.50 \mathrm{~m}$ row spacing, whereas the second had $1.00 \mathrm{~m}$ row spacing. All the treatments were arranged in the same way in both experiments, in a $2 \times 4$ factorial design. The first factor was the nicosulfuron dose applied $\left(0\right.$ and $8 \mathrm{~g}$ a.i. ha $\left.{ }^{-1}\right)$, and the second, the forage seeding rates $(0,2,4$, and
$6 \mathrm{~kg}$ of seeds per hectare). Sowing of both species was performed on the same day.

Results: The application of nicosulfuron negatively affected stomatal conductance, internal carbon concentration, and increased $\mathrm{CO}_{2}$ consumption and efficiency in water use. The photosynthetic rate was not affected by the herbicide application, however it presented lower values in the $0.50 \mathrm{~m}$ spacing. Although the yield was not affected by row spacing, it was higher when nicosulfuron was applied.

Conclusions: The increase in palisade grass density caused detrimental changes in the water use efficiency with direct consequences to the crop yield. The physiological response and corn yield depend on the arrangement of plants and the palisade grass management adopted.

Keywords: Zea mays; Urochloa brizantha; Crop-livestock integration; Photosynthesis; Stomatal conductance

Journal Information:

ISSN - 2675-9462

Website: http://awsjournal.org

Journal of the Brazilian Weed Science Society

How to cite: Freitas MAM, Silva DV, Pereira GAM, Souza WM,

Nunes JJ, Silva AA. Physiological characteristics of corn intercropped with different arrangements of palisade grass plants. Adv Weed Sci. 2021;39;e021230847.

https://doi.org/10.51694/AdvWeedSci/2021;39:00002

Approved by:

Editor in Chief: Aldo Merotto Junior

Conflict of Interest: The authors declare that there is no conflict of interest regarding the publication of this manuscript.

Received: November 8, 2019

Approved: August 10, 2020

* Corresponding author: <jose.junior@jlpesquisa.com.br>

\section{(c) (4)}

This is an open-access article distributed under the terms of the

Creative Commons Attribution License, which permits unrestricted use, distribution, and reproduction in any medium, provided that the original author and source are credited.

Copyright: 2021

\section{Introduction}

Competition from weeds is one of the main biotic factors that limit the corn yield, which in some cases can lead to high productivity losses. Several weed species can be found infesting corn fields, including those belonging to the genus Urochloa (Carvalho et al., 2011). Plants of this genus belong to the same family as corn (Poaceae), which is why they have similar environmental resource requirements, which can interfere with the cash crop development (Costa et al., 2012).

Among the resources for which plants compete, water is considered one of the most limiting factors to their development, especially in hot seasons and low rainfall, which will directly affect photosynthesis and the absorption of nutrients. In this case, an essential characteristic of cultivated plants can be affected: the water use efficiency (WUE), which is characterized as the amount of water transpired by a plant for the production of a certain amount of dry matter (Silva et al., 2007).

The competitive potential of plants for environmental resources varies depending on the species present in the area and the infestation level (Chioderoli et al., 2010), the time of crop emergence, and the competitive characteristics of the cultivars (Carvalho et al., 2011). The competition between weeds and crops results in less access to some resources, which tends to cause deficiencies that culminate in changes in physiological characteristics related to photosynthesis, such as water deficiency (Galon et al., 2013) and low quality or amount of light (Brighenti and Oliveira, 2011). These limitations can lead to changes in stomatal conductance, in the internal concentration of gases, and, consequently, in photosynthetic activity and efficient water use which affects crop yield.

Corn is considered an excellent competitor with smaller species, such as brachiaria, as it can have access to light radiation earlier than smaller species, leading to a more significant accumulation of dry matter produced in the early stages of development (Cardoso et al., 2010). This is mainly because corn has a high capacity for intercepting photosynthetically active radiation, and due to its canopy, which reduces the amount of this resource for other species. This interception varies according to the cultivar's morphological characteristics, such as plant height, leaf shape, the population adopted (Carvalho et al., 2011), crop development, and interference from other species. However, few studies report physiological changes in intercropped plants. 
Therefore, the objective of this work was to evaluate the effects of different plant arrangements and the management of palisade grass on corn's physiological and productive characteristics.

\section{Material and Methods}

Two field experiments were carried out from November 2012 to April 2013 on soil classified as Red-Yellow Argisol. According to previous soil analysis (Table 1), fertilization was carried out at a dose of $400 \mathrm{~kg} / \mathrm{ha} 8-28-16$ (NPK) following corn cultivation recommendations and applied infurrow at planting. Postemergence fertilization consisted of the application of $120 \mathrm{~kg}$ of $\mathrm{N}$ in the form of urea. According to the Koppen-Geiger classification, the region's climate is humid subtropical with dry winters and hot summers, with an average annual temperature of $21{ }^{\circ} \mathrm{C}$ and an average annual rainfall of $1,200 \mathrm{~mm}$. The pluviometric indexes and the average weekly temperatures during the experimental period are shown in Figure 1.

Each experiment corresponded to a plant spacing $(0.50$ or $1.00 \mathrm{~m})$ and was carried out in randomized block design, with four replications. The treatments of the two trials were the same and arranged in a $2 \times 4$ factorial scheme, the first factor being the application or not of the sub-dose of the herbicide nicosulfuron ( $8 \mathrm{~g}$ a.i. ha ${ }^{-1}$, referring to $1 / 5$ of the label rate) and the second factor being the cover crop rate $\left(0,2,4\right.$ and $\left.6 \mathrm{~kg} \mathrm{ha}^{-1}\right)$. The dose of $8 \mathrm{~g}$ a.i. ha ${ }^{-1}$ of nicosulfuron was adopted, as it has already been reported to have potential to suppress palisade grass without interfering in corn yield (Petter et al., 2011).

The experimental area was desiccated by spraying glyphosate $\left(1,080 \mathrm{~g}\right.$ a.i. ha- $\left.{ }^{-1}\right)+2.4-\mathrm{D}\left(540 \mathrm{~g}\right.$ a.i. ha $\left.{ }^{-1}\right)$ seven days before sowing the species. The corn hybrid DKB 390 and Urochloa brizantha (BRS Piatã) vc $76 \%$ seeds were sown on October 20, 2012, with a Semeato SHM 11/13 planter with five rows for the spacing of $0.50 \mathrm{~m}$, and three rows for $1.00 \mathrm{~m}$ spacing. Both trials adopted the same population of 60,000 plants per hectare.

On the same day of corn planting, manual sowing of Urochloa brizantha was also carried out. In the experiment in which corn had an $0.50 \mathrm{~m}$ row spacing, palisade grass was sown in the same row as the corn. In the trial with $1.00 \mathrm{~m}$ row spacing, palisade grass was planted in the same corn row, and between rows $(0.50 \mathrm{~m})$ of corn. The palisade grass seed rate was calculated according to each treatment.
The experimental plots of the two experiments were $30 \mathrm{~m}^{2}$ ( $6 \mathrm{~m}$ wide by $5 \mathrm{~m}$ long) and consisted of six rows of corn for the trial with $1.00 \mathrm{~m}$ row spacing and 12 rows of corn for the trial with $0.50 \mathrm{~m}$ row spacing. For the trial with $1.00 \mathrm{~m}$ row spacing, the useful area of the plot corresponded to the four central rows, excluding $1 \mathrm{~m}$ in length from each end, making up $12 \mathrm{~m}^{2}$ of useful area. For the trial with $0.50 \mathrm{~m}$ row spacing, the eight central rows were evaluated, adopting the same border and the same useful area as the other experiment.

At 60 days after emergence (DAE), when the female inflorescence appeared (embedding), the photosynthetic rate, transpiratory rate, stomatal conductance of water, internal $\mathrm{CO}_{2}$ concentration, and carbon consumption were evaluated, and subsequently, the WUE. For this, a portable infrared gas analyzer (IRGA), model LI-6400 XT was used. The measurements were evaluated between 9 , and 11 am on the same day, on the fully expanded leaf surface in the upper third of each corn plant's crown. In each experimental unit, four plants were analyzed, and in each of these, three observations were made, totaling 12 readings per experimental unit. The average irradiance was $1000 \mu \mathrm{mol}$ of photons $\mathrm{m}^{-2} \mathrm{~s}^{-1}$. This value was determined by the irradiance that affects the leaf surface of the crop, in the position which the leaf was in on the plant, obtained through 30 random evaluations per plot. The evaluated variables were stomatal conductance of water vapors $\left(\mathrm{Gs}-\mathrm{mol} \mathrm{m}^{-2} \mathrm{~s}^{-1}\right)$, transpiration rate $\left(\mathrm{E}-\mathrm{mol} \mathrm{H}_{2} \mathrm{O} \mathrm{m}^{-2} \mathrm{~s}^{-1}\right.$ ), internal $\mathrm{CO}_{2}$ concentration $\left(\mathrm{Ci}-\mu \mathrm{mol} \mathrm{mol}^{-1}\right), \mathrm{CO}_{2}$ consumed $\left(\triangle \mathrm{C}-\mu \mathrm{mol} \mathrm{mol}^{-1}\right)$, photosynthetic rate $\left(\mathrm{A}-\mu \mathrm{mol} \mathrm{m}^{-2} \mathrm{~s}^{-1}\right)$, and water use efficiency (WUE - $\mathrm{mol} \mathrm{CO}_{2} \mathrm{~mol} \mathrm{H}_{2} \mathrm{O}^{-1}$ ).

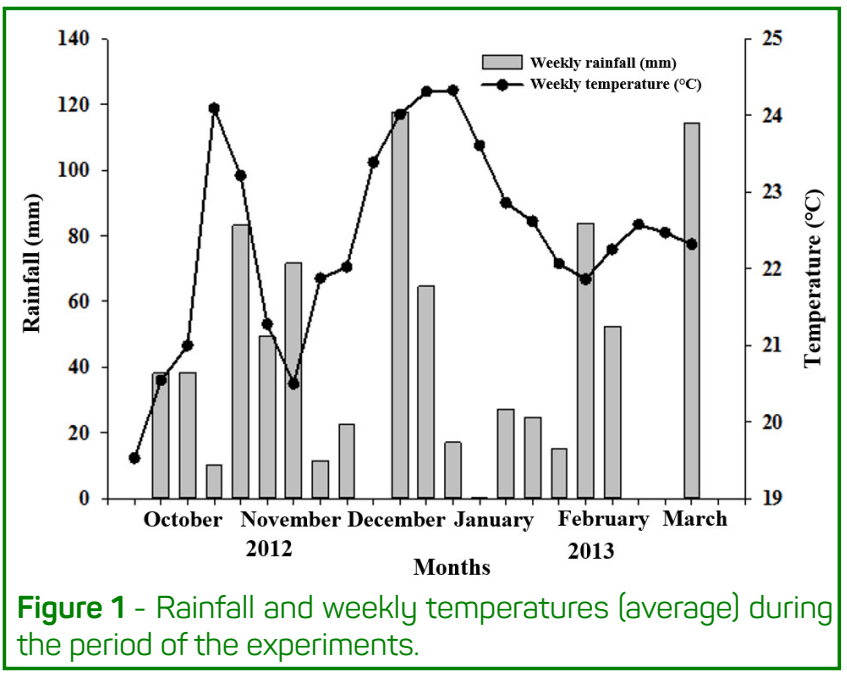

\begin{tabular}{|c|c|c|c|c|c|c|c|c|c|c|c|c|c|}
\hline \multirow{2}{*}{ Solo } & $\mathrm{pH}$ & P & K & $\mathrm{Ca}$ & Mg & Al & $\mathrm{H}+\mathrm{Al}$ & SB & $(\mathrm{t})$ & (T) & v & M & MO \\
\hline & $\left(\mathrm{H}_{2} \mathrm{O}\right)$ & \multicolumn{3}{|c|}{ (mg dm } & \multicolumn{6}{|c|}{$\left(\mathrm{cmol}_{\mathrm{c}} \mathrm{dm}^{-3}\right)$} & \multicolumn{2}{|c|}{ (\%) } & $\operatorname{dag} \mathrm{kg}^{-1}$ \\
\hline Argisol & 5.6 & 5.9 & 64 & 2.0 & 0.8 & 0.3 & 3.3 & 2.96 & 2.96 & 6.26 & 47 & 0 & 2.6 \\
\hline \multicolumn{14}{|c|}{ Physical characteristics (\%) } \\
\hline Texture (\%) & Clay & \multicolumn{5}{|c|}{ Clay $=43$} & \multicolumn{3}{|c|}{ Silt $=14$} & \multicolumn{4}{|c|}{ Sand $=43 \%$} \\
\hline
\end{tabular}

Analyses carried out according to the methodology of the Empresa Brosileira de Pesquisa Agropecuário - Embrapa (Donagema et al., 2011). 
At 150 days after planting (DAP), each plot's entire useful area was harvested, and the grain yield was determined at $13 \%$ moisture.

The analysis of variance for each planting spacing was performed considering the following model: $\mathrm{yij}=\mathrm{m}+\mathrm{ti}+\mathrm{bj}+\mathrm{eij}$. Where yij refers to the observed value of treatment I in repetition $j ; m$ to the general average; ti to the effect of treatment $i$; bj to the effect of block $j$; and eij to the effect of the parcel (error) associated with treatment $\mathrm{i}$ in repetition $j$.

In the variables under study, the ratio between the largest and the smallest mean square of the residue was less than seven for the two planting spacing, meeting the requirement for executing and interpreting the joint variance analysis. Therefore, this analysis was done by adding to the previous model the effect of planting spacing and the interaction between these and treatments $y i j k=m+t i+a j+t a i j+b k(j)+e i k(j)$. Where yijk refers to observation $k$ of treatment $i$ in planting spacing $j$; ti to the effect of treatment $i$; aj to the effect of planting spacing $j$; taij to the effect of the interaction between treatment $i$ and planting spacing $j ; b k(j)$ to the effect of block $k$ within the planting spacing $j$; and eik $(j)$ to the average error. The relevant decompositions of the planting spacing interaction by treatments were also considered in the analysis.

For qualitative variables that showed significance when submitted to the $\mathrm{F}$ test, the Tukey test at $5 \%$ probability was chosen to compare the means. For the quantitative variables, the means were submitted to regression analysis at $5 \%$ probability, adapting the model that best explained the behavior of each variable, following criteria suggested by Gomes (2009).

\section{Results and Discussion}

In the variables under study, the relationship between the largest and the smallest mean square of the residue was less than seven, meeting the requirement for the execution and interpretation of the variance joint analysis (Table 2), as suggested by Gomes (2009).

Corn stomatal conductance (Gs) conducted at $1.00 \mathrm{~m}$ spacing was lower with the application of nicosulfuron (Table 3). Nicosulfuron is an inhibitor of the ALS enzyme (acetolactate synthase), responsible for the synthesis of branched amino acids (leucine, isoleucine, and valine) (Duggleby et al., 2008). Thus, an indirect effect on the physiological characteristics of corn is expected by reducing protein synthesis, considering that they are present in the photosynthetic apparatus responsible for electron transport. Thus, a reduction in the total protein content possibly also affected the electron transport chain. According to Bevilaqua (2019), nicosulfuron can reduce the electron transport rate at varying levels according to each hybrid's characteristics.

Table $\mathbf{3}$ - Average stomatal conductance $\left(\mathrm{Gs}-\mathrm{mol} \mathrm{m}^{-1} \mathrm{~s}^{-1}\right)$
of corn plants in two row spacings and in the presence and
absence of nicosulfuron.

Means followed by the same lowercase letters in the row and uppercase letters in the column do not differ by Tukey's test at $5 \%$ probability.

Table 2 - Analysis of variance (mean squares) and variation coefficient (cv) corresponding to stomatal conductance (Gs), internal carbon concentration $(\mathrm{Ci})$, carbon consumption $\left(\Delta \mathrm{CO}_{2}\right)$, transpiratory rate $(\mathrm{E})$, photosynthetic rate $(\mathrm{A})$, water use efficiency (WUE), and corn yield.

\begin{tabular}{|c|c|c|c|c|c|c|c|c|}
\hline \multirow{2}{*}{ FV } & \multirow{2}{*}{ GL } & \multicolumn{7}{|c|}{ Mean squares } \\
\hline & & Gs & $\mathrm{Ci}$ & $E$ & $\Delta \mathrm{CO}_{2}$ & A & EUA & PROD \\
\hline Blocks/Spacing & 6 & $0.005^{*}$ & 3,072.18 & 2.520 & 6.64 & 27.15 & 2.75 & $183,299.84$ \\
\hline Row spacing (S) & 1 & $0.087^{*}$ & $128,255.00$ & 34.120 & $562.00^{*}$ & $650.70^{*}$ & 2.76 & $134,157.38$ \\
\hline Herbicide (H) & 3 & $0.032^{*}$ & $20,426.24^{*}$ & 8.030 & 28.4 & 7.77 & $5.74^{*}$ & $1,845,590.17^{*}$ \\
\hline $\mathrm{S} \times \mathrm{H}$ & 1 & $0.037^{*}$ & 2,799.10 & 5.430 & 3.58 & 55.41 & 0.26 & $14,119.38$ \\
\hline Density (D) & 3 & 0.004 & 2,329.31 & 4.290 & 2.10 & 24.65 & $2.97^{*}$ & $1,446,291.87^{*}$ \\
\hline$S \times D$ & 1 & $0.003^{*}$ & $4,815.36^{*}$ & 1.110 & 3.39 & 5.16 & 0.12 & $414,738.24$ \\
\hline $\mathrm{D} \times \mathrm{H}$ & 3 & 0.001 & $2,632.67$ & 0.110 & 4.55 & 8.54 & 0.10 & $427,031.36$ \\
\hline $\mathrm{D} \times \mathrm{S} \times \mathrm{H}$ & 3 & 0.002 & $8,161.84$ & $2.900^{*}$ & 13.39 & 29.45 & 0.57 & $145,934.28$ \\
\hline Residue & 42 & 0.002 & $1,313.55$ & 0.782 & 8.38 & 16.25 & 0.75 & $574,237.52$ \\
\hline CV\% & & 29.000 & 1.16 & 21.000 & 15.70 & 28.00 & 23.00 & 8.00 \\
\hline
\end{tabular}

* F Significant at 5\% probability. 
According to Agostinetto et al. (2016), the application of metribuzin, metsulfuron, and 2,4-D also reduced stomatal conductance and other parameters, such as photosynthetic rate and transpiration, in wheat 120 hours after application of herbicides under greenhouse conditions. This is the same for rice when subjected to the application of carfentrazoneethyl, which had its stomatal conductance reduced, a fact pointed out by the authors as a response to the stress imposed by the application of the herbicide, which can affect, besides this, other photosynthetic parameters (Langaro et al., 2016). Balabanova et al. (2016) attributed the reduction in stomatal congestion as one of the factors responsible for reducing the net photosynthetic rate of the Clearfield ${ }^{\circledR}$ sunflower when subjected to imazamox application.

Although nicosulfuron is selective to corn, this is directly linked to the choice of the correct hybrid, the stage of the application, and the dose used. Furthermore, applications of organophosphate insecticides or nitrogen fertilization at intervals close to the application of the herbicide can compromise the selectivity and cause phytointoxication even in hybrids with tolerance (Devkota et al., 2013; Guerra et al., 2010; Maciel et al., 2018).

The internal concentration of $\mathrm{CO}_{2}(\mathrm{Ci})$ was higher in corn plants grown at the $0.50 \mathrm{~m}$ row spacing associated with the nicosulfuron sub dose (Figure 2). It is noteworthy that $\mathrm{Ci}$ is inversely proportional to photosynthetic capacity and $\mathrm{CO}_{2}$ consumption. Therefore, a lower $\mathrm{Ci}$ indicates less $\mathrm{CO}_{2}$ consumed and a lower photosynthetic rate (Flexas et al., 2014).

In the row spacing of $0.50 \mathrm{~m}$, both in the presence and in the absence of nicosulfuron, higher values of $\mathrm{Ci}$ were observed for corn plants as well as a tendency for this variable to decrease - the internal $\mathrm{CO}_{2}$ concentration $\left(\mathrm{Ci}-\mu \mathrm{mol} \mathrm{mol}{ }^{1}\right)$ - with an increase in the density of brachiaria plants. In the absence of the herbicide, $\mathrm{C} i$ was constant

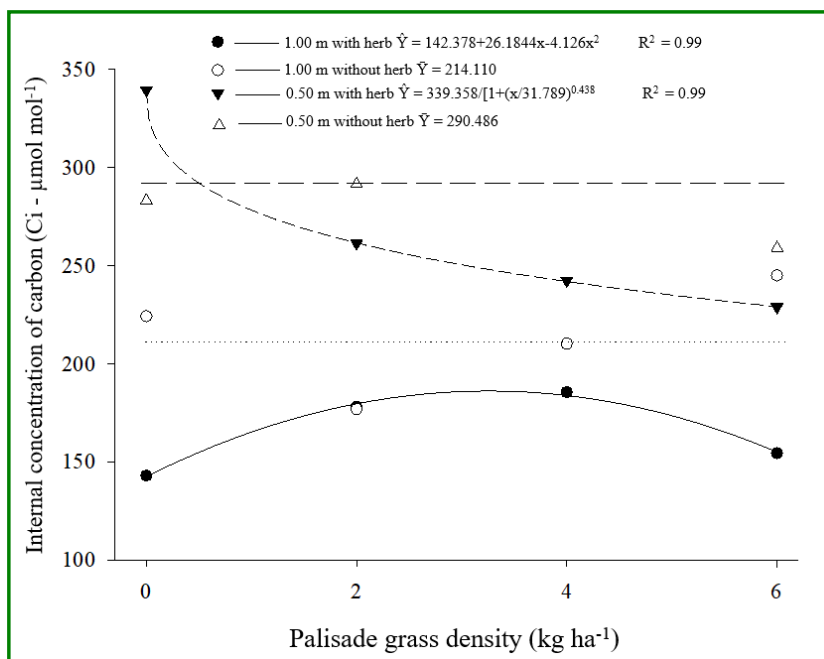

Figure 2 - Corn internal concentration of carbon in two row spacings and in the presence and absence of the herbicide nicosulfuron in different densities of palisade grass plants. regardless of the density of palisade grass growing with corn. In the 1.00 row spacing with herbicide application, $C$ i showed quadratic behavior with a tendency to increase to a density of approximately $3 \mathrm{~kg} \mathrm{ha}^{-1}$ and reduction from values greater than $3 \mathrm{~kg} \mathrm{ha}^{-1}$ (Figure 2).

Makino et al. (2015), working with corn in 0.45 and $0.90 \mathrm{~m}$ row spacings intercropped or not with two populations of Brachiaria ruziziensis (10 and 20 plants $\mathrm{m}^{-2}$ ), observed greater effects of planting spacing than intercropping with forage in most of the analyzed variables. The authors also observed higher concentrations of $\mathrm{Ci}$ in the narrower row spacing, and although the single or intercropped cultivation did not differ, the increase in the brachiaria population resulted in a higher internal carbon concentration.

Corn plants showed higher $\mathrm{CO}_{2}$ consumption $(\Delta C)$ when grown at $1.00 \mathrm{~m}$ row spacing, regardless of herbicide treatment and density of $U$. brizantha (Table 4). Nunes and Ceccon (2011) evaluated the development of three corn hybrids in 0.45 and $0.90 \mathrm{~m}$ row spacing and observed higher $\mathrm{CO}_{2}$ consumption in the wider row spacing for all evaluated hybrids. According to the authors, the rate of $\mathrm{CO}_{2}$ consumption is correlated with photosynthetic intensity at the time of evaluation, so the higher the consumption, the faster the plant's metabolism. Makino et al. (2015) observed greater consumption in the narrow row spacing $(0.45 \mathrm{~m})$. According to the authors, the use of reduced spacing reflects a better distribution of the plants in the area, which favors the use of the environment's resources and results in a greater photosynthetic potential.

The transpiratory rate (E) of corn at $1.00 \mathrm{~m}$ row spacing was lower with the presence of nicosulfuron compared to the absence of the herbicide. In the narrow row spacing $(0.50 \mathrm{~m})$, no statistical difference was observed for this variable, regardless of the herbicide application (Table 5). $\mathrm{E}$ is mainly determined by $\mathrm{Gs}$ and two physical variables: radiation and deficit in atmospheric saturation (Dalmolin et al., 2015). The other variables were not correlated with each other. Nunes and Ceccon (2011) observed a reduction in corn's transpiration at a row spacing of $0.45 \mathrm{~m}$ compared to $0.90 \mathrm{~m}$. According to the authors, transpiration is the ability of the root system to replace the water lost by the leaves. As the $0.45 \mathrm{~m}$ row spacing contained a higher population of plants per hectare, it is assumed that there was greater intraspecific competition among corn plants for water.

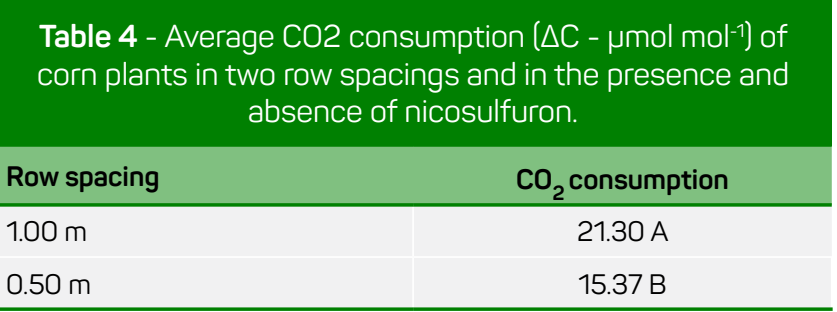

Means followed by the same capital letters in the column do not differ statistically from each other by the $F$ test at $5 \%$ probability. 
Table 5 - Average of the transpiratory rate of corn plants $\left(E-m o l ~ H 2 O ~ m^{-2} s^{-1}\right)$ in two row spacings and in the presence and absence of nicosulfuron.

\begin{tabular}{|c|c|c|c|c|c|c|c|c|}
\hline \multirow{3}{*}{$\begin{array}{l}\text { Nicosulfuron } \\
\text { (8 g a.i. ha-1] }\end{array}$} & \multicolumn{8}{|c|}{ Sowing density of $U$. brizantha (kg ha-1) } \\
\hline & \multicolumn{2}{|c|}{0} & \multicolumn{2}{|c|}{2} & \multicolumn{2}{|c|}{4} & \multicolumn{2}{|c|}{6} \\
\hline & \multicolumn{8}{|c|}{ Row spacing } \\
\hline & $1.00 \mathrm{~m}$ & $0.50 \mathrm{~m}$ & $1.00 \mathrm{~m}$ & $0.50 \mathrm{~m}$ & $1.00 \mathrm{~m}$ & $0.50 \mathrm{~m}$ & $1.00 \mathrm{~m}$ & $0.50 \mathrm{~m}$ \\
\hline Presence & 3.54 Ba & 3.30 Aa & 4.30 Aa & $2.49 \mathrm{Ab}$ & 4.35 Ba & 4.23 Aa & $4.65 \mathrm{Ba}$ & $3.31 \mathrm{Ab}$ \\
\hline Absence & $5.06 \mathrm{Aa}$ & $3.10 \mathrm{Ab}$ & $4.12 \mathrm{Aa}$ & 3.64 Aa & 6.47 Aa & $3.85 \mathrm{Ab}$ & 6.34Aa & 3.23Ab \\
\hline
\end{tabular}

Means followed by the same lowercase letters in the row and uppercase letters in the column do not differ by Tukey's test at $5 \%$ probability.

Transpiration reduction is associated with stoma closure, and variations in stoma opening cause water potential changes, as they act on $\mathrm{E}$ (Manabe et al., 2014). The plant tends to close the stomata in less favorable situations of radiation or water. These parameters are linked in a cost/ benefit ratio since $\mathrm{E}$ is also a mechanism for decreasing leaf temperature. Transpiration, $\mathrm{CO}_{2}$ capture, and stomatal conductance $(\mathrm{Gs})$ processes only occur when the stomata are open. Due to the latent heat of evaporation (heat effectively used to "heat" water and allow evaporation), transpiration has a powerful cooling effect important in regulating the leaf temperature (Mendes et al., 2013).

In the plots cultivated with $1.00 \mathrm{~m}$ row spacing, with and without nicosulfuron, corn showed higher transpiratory rate values (E) when grown with all palisade grass densities compared to the plots cultivated in the $0.50 \mathrm{~m}$ row spacing. Plants treated with nicosulfuron at $1.00 \mathrm{~m}$ spacing showed an increase in $\mathrm{E}$ values inline with the increase in quantity of palisade grass plants (Figure 3 ).

According to Concenço et al. (2012, 2014), imazamox is an ALS-inhibiting herbicide that acts indirectly on the system, and the presence of this herbicide together with atrazine (photosystem II inhibitor) reduces stomatal conductance in plants sensitive to this product, as well as many tolerant plants. This usually occurs due to the

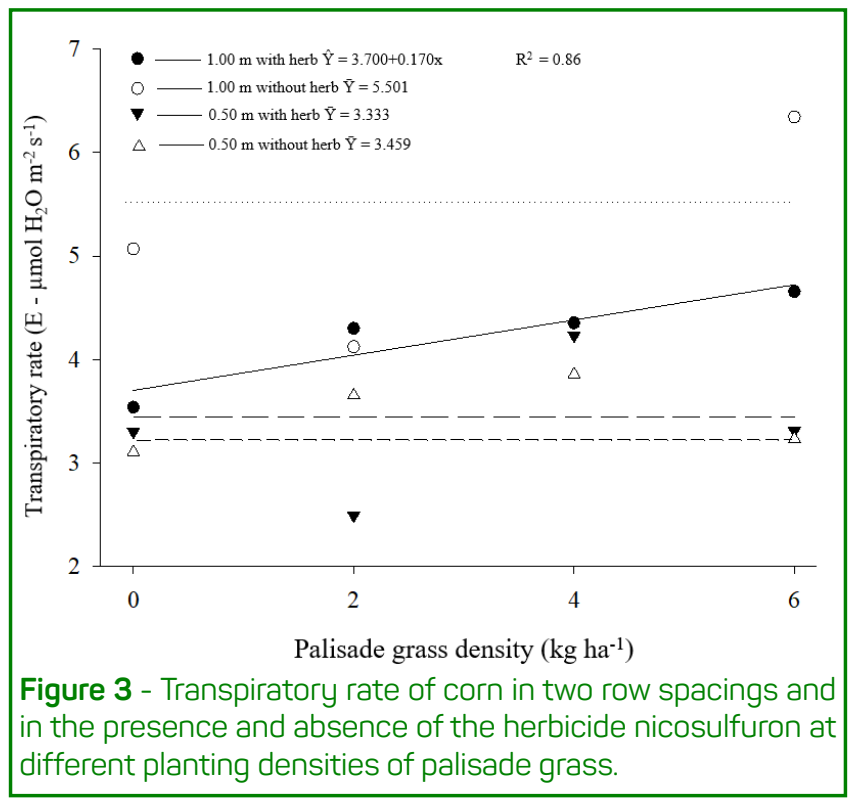

closure of stomata, which is influenced by several factors, such as water availability, light and energy, pollution, and herbicides used to control weeds (Torres et al., 2012).

Regarding the photosynthetic rate (A), no difference was observed between treatments with and without the herbicide. However, it was greater for the $1.00 \mathrm{~m}$ row spacing independent of the herbicide (Table 6). The results corroborated with Nunes and Ceccon (2011), where the authors observed a higher photosynthetic rate in single cultivated corn with row spacing of $0.90 \mathrm{~m}$, compared to $0.45 \mathrm{~m}$.

The competition between weeds and crops is a critical factor for developing the crop when the weed is established next to or before the crop (Pereira et al., 2012). However, if the crop is established first, depending on the cultivated species, vigor, initial growth speed, and planting density, it can quickly cover the soil, excluding or inhibiting the growth of forages significantly. Makino et al. (2017), evaluating the cultivation of double-crop corn in different spatial arrangements, observed a reduction in the photosynthetic rate when the plant population increased from 45,000 to 65,000 plants ha $^{-1}$. According to the authors, the lower photosynthetic rate reflected the reduction in stomatal conductance, transpiration, and the consumption of $\mathrm{CO}_{2}$ with the largest population of plants.

It is known that stresses caused by herbicides can affect stomatal conductance, and the ability of corn hybrids to tolerate nicosulfuron lies in the ability to degrade the herbicide quickly and thus prevent oxidative stress that leads to $\mathrm{O}_{2}$ and $\mathrm{H}_{2} \mathrm{O}_{2}$ accumulation (Concenço et al., 2014; Wang et al., 2018). Torres et al. (2012) also found a high correlation between A and Gs.

Corn plants grown at $1.00 \mathrm{~m}$ row spacing showed greater WUE when compared to plants grown at $0.50 \mathrm{~m}$ row spacing. The WUE was greater when they were in the presence of the herbicide (Table 7). The most efficient use

\begin{tabular}{l}
$\begin{array}{l}\text { Table } 6 \text { - Average photosynthetic rate }\left(\mathrm{A}-\mu \mathrm{mol} \mathrm{m}^{-2} \mathrm{~s}^{-1}\right) \text { of } \\
\text { corn plants in two row spacings and in the presence and } \\
\text { absence of nicosulfuron. }\end{array}$ \\
$\begin{array}{l}\text { Row spacing } \\
\text { Photosynthetic rate }\end{array}$ \\
\hline $\begin{array}{l}1.00 \mathrm{~m} \\
0.50 \mathrm{~m}\end{array}$
\end{tabular}

Means followed by the same capital letters in the column do not differ statistically from each other by the $F$ test at $5 \%$ probability. 
of water is directly related to the stomatal opening time, as, while carbon dioxide $\left(\mathrm{CO}_{2}\right)$ penetrates the leaf, water is lost through transpiration, with varying intensity, depending on the potential gradient between the leaf surface and the atmosphere (Galon et al., 2013).

For all the row spacings evaluated with and without the herbicide, the tendency was to reduce the WUE with the increase in the density of forage (Figure 4). It should be noted that the WUE represents the amount of $\mathrm{CO}_{2}$ fixed for the production of dry biomass according to the amount of water transpired. The improvement in the WUE by corn plants is due to the reduction in the growth rate of the palisade grass due to the application of the herbicide, since the lower growth of the palisade grass plants reduces the competition with corn plants for nutrients and, mainly, for water. Galon et al. (2013), working with biotypes of Conyza bonariensis resistant to glyphosate, observed that the increase in the density of the sensitive biotype in competition with the resistant biotype caused a reduction in the WUE of this biotype with an increase in the density of the opposite biotype.

According to Makino et al. $(2016,2017)$, the cultivation of corn intercropped with palisade grass allows the best WUE even in wide row spacing $(0.90 \mathrm{~m})$, since intercropping with the forage resulted in lower rates of transpiration, leaf temperature, internal $\mathrm{CO}_{2}$ accumulation, and stomatal conductance, factors which contributed to the best final crop yield in this system.

\begin{tabular}{|c|c|}
\hline Nicosulfuron (8 g a.i. ha-1) & Water use efficiency \\
\hline Presence & $3.95 \mathrm{~A}$ \\
\hline Absence & $3.36 \mathrm{~B}$ \\
\hline
\end{tabular}

Means followed by the same capital letters in the column do not differ by the $\mathrm{F}$ test at $5 \%$ probability.

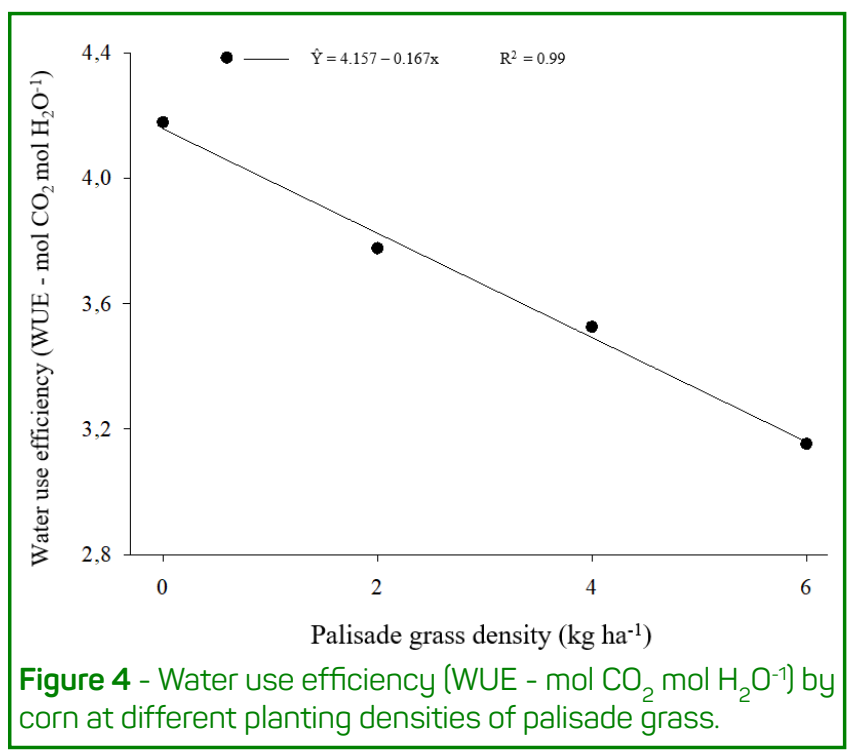

No statistical difference was observed regarding corn yield between the row spacings adopted. However, when the crop was grown in the presence of herbicide, a higher yield was observed (Table 8). Santos et al. (2015) concluded that regardless of how the forage was established with the crop, the use of the herbicide nicosulfuron in a mixture with atrazine was necessary to achieve adequate control over most of the weeds present in this cropping system, allowing with this production management of corn compatible with forage production.

Petter et al. (2011), evaluating the selectivity of different herbicides for the cultivation of corn intercropped with Brachiaria ruziziensis, observed that the best option was nicosulfuron at the dose of $8 \mathrm{~g}$ a.i. ha ${ }^{-1}$, considering that it was the only treatment that suppressed the forage and did not adversely affect crop yield. Cholette et al. (2019), evaluating doses of nicosulfuron for the suppression of ryegrass (Lolium multiflorum) sown in consortium with corn in Canada, observed that the use of the herbicide in doses close to $25 \mathrm{~g}$ a.i. ha ${ }^{-1}$ promoted the best yields of the culture by the imposed ryegrass suppression, while non-suppression reduced corn yield by $6 \%$. Despite the need to use herbicides to help the consortium, few selective chemical options are available due to brachiaria species' sensitivity to herbicides. According to Moraes et al. (2019), doses between 30 and $62 \mathrm{~g}$ a.i. ha $\mathrm{a}^{-1}$ of glyphosate have already been sufficient to reduce the growth of Urochloa decumbens plants by $50 \%$.

For all row spacings evaluated with and without application of $1 / 5$ of the herbicide label rate, there was a trend of decreasing yield with increasing density of the palisade grass (Figure 5). This can be explained because

Table 8 - Corn yield average $\left(\mathrm{kg} \mathrm{ha}^{-1}\right)$ in two row spacings and in the presence and absence of nicosulfuron.

\begin{tabular}{lc} 
Nicosulfuron $\left(\mathbf{8} \mathbf{g}\right.$ a.i. ha $^{-1}$ ) & Yield \\
\hline Presence & $9,738.45 \mathrm{~A}$ \\
\hline Absence & $9,398.81 \mathrm{~B}$ \\
\hline
\end{tabular}

Means followed by the same capital letters in the column do not differ statistically from each other by the $\mathrm{F}$ test at $5 \%$ probability.

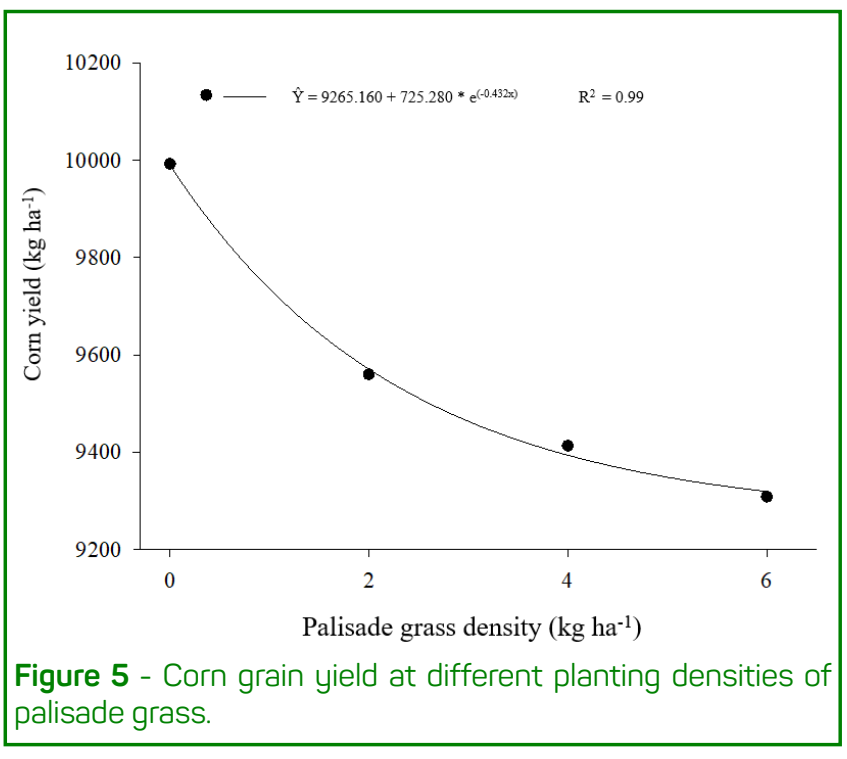


the increase in density and the reduction of row spacing between corn plants negatively affected most of the corn's physiological variables, directly related to the crop's yield potential.

According to Ceccon et al. (2014), evaluating the performance of single corn and intercropping with increasing populations of Brachiaria ruziziensis ( 0 to 45 plants $\mathrm{m}^{-2}$ ) grown at $0.45 \mathrm{~m}$ row spacing, also observed a reduction in the final crop yield with the increase of the forage population. Ceccon et al. (2018) observed a quadratic reduction for the increase in the population of Brachiaria ruziziensis (42 $\mathrm{kg} \mathrm{ha}^{-1}$ per plant $\mathrm{m}^{-2}$ ) and a linear reduction for Brachiaria brizantha (13.39 $\mathrm{kg} \mathrm{ha}^{-1}$ per plant $\mathrm{m}^{-2}$ ). Despite the reduction in yield, the authors consider the consortium a viable option due to other benefits. Although several studies report variable levels of reduction in corn yield when grown intercropped with palisade grass, it is regarded as a reasonable assumption among those authors that even in these situations, it is a viable cultivation modality due to other benefits offered by the system and often the reduction in yield is low (Alves et al., 2013; Cunha-Chiamolera et al., 2017; Ikeda et al., 2007; Maia et al., 2014; Silva et al., 2015;).

\section{Conclusions}

Palisade grass sowing density, row spacing, and the application of nicosulfuron affected the crop's physiological characteristics. In general, the reduction of the row spacing and the increase in the density of palisade grass plants reduced most of the physiological variables evaluated. This resulted in a progressive reduction in corn yield due to the increase in the forage population. However, with the nicosulfuron sub dose, losses in the grain yield of the crop were lower.

\section{Author's contributions}

DVS: Collaboration in the installation, conduction, data collection, evaluation, and data analysis of the experiment, writing of the Manuscript. GAMP: Collaboration in the installation, conduction, data collection, evaluation, and data analysis of the experiment, writing of the manuscript. WMS: Collaboration in the installation, conduction, data collection, evaluations, and data analysis of the experiment. JJN: Collaborations in revising and updating the manuscript writing; diagramming and framing in the current norms of the periodic. AAS: Professor advisor of the project: Supervision and collaboration in the installation, conduction, data collection, evaluations, and data analysis of the experiment, writing of the manuscript.

\section{Acknowledgements}

Instituto Federal de Educação Ciência e Tecnologia Goiano (IF Foiano Campus Urutaí); Laboratório de Fitotecnia da Universidade Federal de Viçosa (UFV).

\section{Funding}

Coordenação de Aperfeiçoamento de Pessoal de Nível Superior (Capes); Conselho Nacional de Desenvolvimento Científico e Tecnológico (CNPq) and Fundação de Amparo à Pesquisa do Estado de Goiás (FAPEG).

\section{References}

Agostinetto D, Perboni LT, Langaro AC, Gomes J, Fraga DS, Franco $\mathrm{JJ}$. Changes in photosynthesis and oxidative stress in wheat plants submmited to herbicides application. Planta Daninha. 2016;34(1):1-9. Available from: https://doi.org/10.1590/S0100-83582016340100001

Alves VB, Padilha NS, Garcia RA, Ceccon G. [Urochloo ruziziensis populations and soybean yield in succession]. Rev Bras Milho Sorgo. 2013;12(3):280-92. Portuguese. Available from: https://doi.org/10.18512/1980-6477/rbms.v12n3p280-292

Balabanova DA, Paunov M, Goltsev V, Cuypers A, Vangronsveld J, Vassilev A. Photosynthetic performance of the imidazolinone resistant sunflower exposed to single and combined treatment by the herbicide imazamox and an amino acid extract. Front Plant Sci. 2016;7:1559. Available from: https://doi.org/10.3389/fpls.2016.01559

Bevilaqua NC. [Dynamics and action of nicosulfuron on corn hybrids] [dissertation]. Botucatu: Faculdade de Ciências Agronômicas, Universidade Estadual Paulista Júlio de Mesquita Filho; 2019. Portuguese.

Brighenti AM, Oliveira MF. Biologia de plantas daninhas. In: Oliveira Júnior RS, Constantin J, Inoue MH, editores. Biologia e manejo de plantas daninhas. Curitiba: Omnipax; 2011. p. 1-36.
Cardoso GD, Alves PL, Beltrão NE, Vale LS. [Winter maize intercropped with [Weeds interference periods in naturally colored cotton 'BRS Safira']. Rev Cienc Agron. 2010;41(3):456-62. Portuguese. Available from: https://doi.org/10.1590/S1806-66902010000300019

Carvalho FP, Santos JB, Cury JP, Valadão Silva D, Braga RR, Byrro EC. [Alocation of dry matter in maize cultivars in competition with weed]. Planta Daninha. 2011;29(2):373-82. Portuguese. Available from: https://doi.org/10.1590/S0100-83582011000200015

Ceccon G, Silva JF, Luiz Neto A, Makino PA, Santos A. [Yield of late season maize at reduced spacing with populations of maize and Brochiario ruziziensis]. Rev Bras Milho Sorgo. 2014;13(3):326-35. Portuguese. Available from: https://doi.org/10.18512/1980-6477/rbms.v13n3p326-335

Ceccon G, Silva JF, Makino PA, Luiz Neto A. [Intercroping maize-brachiaria with forage plant population in the mid-south of Brazil]. Rev Bras Milho Sorgo. 2018;17(1):157-67. Portuguese. Available from: https://doi.org/10.18512/1980-6477/rbms.v17n1p157-167

Chioderoli CA, Mello LM, Grigolli PJ, Silva JO, Cesarin AL [Consortium of pasture with fall corn in no tillage under center pivot]. Eng Agric. 2010;30(6):1101-9. Portuguese. Available from: https://doi.org/10.1590/S0100-69162010000600011 
Cholette TB, Soltani N, Hooker DC, Robinson DE, Sikkema PH. Suppression of annual ryegrass in corn with nicossulfuron. Weed Technol. 2019;33(1):173-7. Available from: https://doi.org/10.1017/wet.2018.106

Concenço G, Aspiazú I, Ferreira EA, Galon L, Silva AF. Physiology of crops and weeds under biotic and abiotic stresses. In: Najafpour $N$, Najafpour MM, editores. Applied photosynthesis. Rijeka, Croatia: InTech; 2012. p. 257-80 [cited 2019 Nov 5]. Available from: https:// www.intechopen.com/books/applied-photosynthesis/physiology-of-crops-and-weeds-under-biotic-and-abiotic-stresses

Concenço G, Ferreira EA, Marques RF, Nunes TC, Santos SA, Palharini WG, et al. [Physiological traits of Crambe abyssinica under herbicide application]. Rev Ciênc Agrár. 2014;37(3):361-9. Portuguese.

Costa NR, Andreotti M, Gameiro RA, Pariz CM, Buzetti S, Lopes KS. [Nitrogen fertilization in the intercropping of corn with two Brachiaria species in a no-tillage system]. Pesq Agropec Bras. 2012;47(8):1038-47. Portuguese. Available from: https://doi.org/10.1590/S0100-204X2012000800003

Cunha-Chiamolera TP, Carmeis Filho AC, Mingotte FL, Chiamolera FM, Lemos LB. [Residual nitrogen on maize and $U$. ruziziensis intercropped in succession to common bean]. Rev Bras Milho Sorgo. 2017;16(2):328-36. Portuguese. Available from: https://doi.org/10.18512/1980-6477/rbms.v16n2p328-336

Dalmolin AC, Thomas SE, Almeida BC, Ortíz CE. [Morphophysiological alterations in young plants of Curatella americana $\mathrm{L}$. subjected to shading]. Rev Bras Biocienc. 2015;13(1):41-8. Portuguese

Devkota P, Berger S, Ferrell J, Dittmar P. Diagnosing herbicide injury in corn. 2013 Jan [cited 2019 Oct 10]. (University of Florida Extension SS-AGR-365). Available from: https://edis.ifas.ufl.edu/pdffiles/AG/AG37400.pdf

Donagema GK, Campos DV, Calderano SB, Teixeira WG, Viana JH, organizadores. Manual de métodos de análise de solos. 2a ed. Rio de Janeiro: Embrapa Solos; 2011.

Duggleby RG, McCourt JA, Guddat LW. Structure and mechanism of inhibition of plant acetohydroxyacid synthase. Plant Physiol Biochem. 2008;46(3):309-24. Available from: https://doi.org/10.1016/j.plaphy.2007.12.004

Flexas J, Carriquí M, Coopman RE, Gago J, Galmés J, Martorell S, et al. Stomatal and mesophyll conductances to $\mathrm{CO}_{2}$ in different plant groups: underrated factors for predicting leaf photosynthesis responses to climate change? Plant Sci. 2014;226:41-8. Available from: https://doi.org/10.1016/j.plantsci.2014.06.011

Galon L, Ferreira EA, Concenço G, Silva AA, Silva DV, Silva AF, et al. [Physiological characteristics of Conyza bonariensis biotypes resistant to glyphosate cultivated under competition]. Planta Daninha. 2013;31(4):859-66. Portugues. Available from: https://doi.org/10.1590/S0100-83582013000400012

Gomes FP. Curso de estatística experimental. Piracicaba: FEALQ; 2009.

Guerra N, Maciel CDG, Oliveira Neto AM, Poletine JP, Lima GGR, Sola Júnior LC. [ Selectivity of nicosulfuron formulations for corn hybrids in function of nitrogen fertilization period]. Rev Bras Herbic. 2010;9(3):8999. Portuguese. Available from: https://doi.org/10.7824/rbh.v9i3.86
Ikeda FS, Mitja D, Vilela L, Carmona R. [Soil seedbank in integrated crop-pasture systems]. Pesq Agropec Bras. 2007;42(11):1545-51. Available from: https://doi.org/10.1590/S0100-204X2007001100005

Langaro AC, Agostinetto D, Oliveira C, Silva JD, Bruno MS. Biochemical and physiological changes in rice plants due to the application of herbicides. Planta Daninha. 2016;34(2):277-89. Available from: https://doi.org/10.1590/S0100-83582016340200009

Maciel CD, Silva AA, Helvig EO, Oliveira Neto AM, Guerra N, Sola Júnior LC, et al. [Selectivity of herbicides and insecticides tank mixtures applied in maize hybrids]. Rev Bras MIlho Sorgo. 2018;17(2):287-302. Portuguese. Available from: https://doi.org/10.18512/1980-6477/rbms.v17n2p287-302

Maia GA, Pinho Costa KA, Costa Severiano E, Epifanio PS, Neto JF, Ribeiro $M G$, et al. Yield and chemical composition of brachiaria forage grasses in the offseason after corn harvest. Am J Plant Sci. 2014;5(07):933-41. Available from: https://doi.org/10.4236/ajps.2014.57106

Makino PA, Fachinelli R, Melo TS, Ceccon G. Eficiência fotossintética e produtividade de milho safrinha em arranjos de plantas. In: Anais do 14. Seminário Nacional de Milho Safrinha; 21-23 nov 2017; Cuiabá. Cuiabá: Fundação MT; 2017. p. 158-63.

Makino PA, Fachinelli R, Ribeiro LM, Santos AL, Leite EM, Ceccon G. Fotossíntese e componentes de produtividade de milho verão em diferentes populações de milho solteiro e consorciado com braquiária. In: Anais do 31. Congresso Nacional de Milho e Sorgo; 25-29 set 2016; Bento Gonçalves. Bento Gonçalves: ABMS; 2016. p. 707.

Makino PA, Ribeiro LM, Santos AL, Mechi IA, Fachinelli R, Ceccon G. Atividade fotossintética em folhas de milho solteiro e consorciado com braquiária em dois espaçamentos. Anais do 13. Seminário Nacional de Milho Safrinha; 24-26 nov 2015; Maringá. Maringá: Universidade Estadual de Maringá; 2015.

Manabe PM, Matos CC, Ferreira EA, Silva AA, Sediyama T, Manabe A, et al. [Physiological characteristics of beans in competition with weed]. Biosci J. 2014;30(6):1721-8. Portuguese.

Mendes MM, Lacerda CF, Cavalcante AC, Fernandes FE, Oliveira TS. [Development of maize under influence of "pau-branco" trees in an agrosilvopastoral system]. Pesq Agropec Bras. 2013;48(10):1342-50. Portuguese. Available from: https://doi.org/10.1590/S0100-204X2013001000005

Moraes CP, Tropaldi L, Brito IP, Carbonari CA, Velini ED. [Determination of control dose of Urochloa decumbens by the glyphosate application]. Rev Bras Herbic. 2019;18(1):1-6. Portuguese. Available from: https://doi.org/10.7824/rbh.v18i1.618

Nunes AS, Ceccon G. [Photosynthetic efficiency in corn plants single and intercropped with Brochioria ruziziensis]. In: Anais do 11. Seminário Nacional de Milho Safrinha; 21-23 nov. 2011; Lucas do Rio Verde. Lucas do Rio Verde: Fundação Rio Verde; 2011. p. 165-72. Portuguese.

Pereira GA, Lemos VT, Santos JB, Ferreira EA, Silva DV, Oliveira MC, et al. [Growth of cassava and weed in response to phosphate fertilizer]. Rev Ceres. 2012;59(5):716-22. Portuguese. Available from: https://doi.org/10.1590/S0034-737X2012000500019 
Petter FA, Pacheco LP, Procópio So, Cargnelutti Filho A, Volf MR. [Selectivity of herbicides to corn and braquiária grass Intercropping in a crop-Livestock Integration System] Semin Cienc Agrar. 2011;32(3):855-64. Portuguese. Available from: https://doi.org/10.5433/1679-0359.2011v32n3p855

Santos MV, Silva DV, Fonseca DM, Reis MR, Ferreira LR, Oliveira Neto $\mathrm{SN}$, et al. [Productive components of maize under different weed management systems and planting arrangements in agrosilvopasture system]. Cienc Rural. 2015;45(9):1545-50. Portuguese. Available from: https://doi.org/10.1590/0103-8478cr20141224

Silva AA, Ferreira FA, Ferreira LR, Santos JB. Biologia de plantas daninhas. In: Silva AA, Silva JF, editores. Tópicos em manejo de plantas daninhas. Viçosa: Editora UFV; 2007. p. 17-61.
Silva DV, Pereira GA, Moreira MA, Silva AA, Sediyama T, Silva GS, et al. [Nutritional efficiency of maize in intercropping with signalgrass]. Cienc Rural. 2015;45(8):1394-400. Portuguese. Available from: https://doi.org/10.1590/0103-8478cr20140760

Torres LG,FerreiraEA, RochaPR, FariaAT,GonçalvesVA, Galon L, etal. [Changes in the physiological characteristics of sugarcane cultivars submitted to herbicide application]. Planta Daninha. 2012;30(3):581-7. Portuguese. Available from: https://doi.org/10.1590/S0100-83582012000300014

Wang J, Zhong $X$, Li $F$, Shi Z. Effects of nicosulfuron on growth, oxidative damage, and the ascorbate-glutathione pathway in paired nearly isogenic lines of waxy maize (Zea mays L.). Pestic Biochem Physiol. 2018;145:108-17. Available from: https://doi.org/10.1016/j.pestbp.2018.01.015 